\title{
9 The spatial differentiation of migration in Poland and Ukraine
}

\author{
Nataliia Chugaievska and Daniela Szczepaniak
}

\subsection{Introduction}

It is difficult to single out one reason that forces people to leave their place of residence and migrate to another country. Everything depends on the specific set of motives of a person who has the desire and right to choose an optimal place of residence and work for himself, and thus meet his material, professional and spiritual needs.

Homoncik et al. (2017) emphasize that foreign migrations are a socioeconomic phenomenon that has become permanently engrained in Poland's contemporary history. The Poles' Migration for Work report (2016) indicates that $78.8 \%$ of migrants indicate higher earnings as the main reason for emigration. Other important motives are a higher standard of living (58.9\%), the opportunity to travel and explore the world (44.0\%), better social conditions $(37.3 \%)$ and better career prospects $(35.7 \%)$.

In the second decade of the 21st century, Poland became for Ukraine's citizens one of the leading labor markets among all other countries of the European Union. This is favored primarily by liberal procedures for legalizing one's stay, obtaining employment, geographical and cultural proximity, as well as the extremely attractive human potential of Ukraine (Zubik, 2014).

This chapter is part of the problem of migration research in a regional and local perspective. The analyses conducted here relate to the spatial differentiation of the rates of migration inflows and outflows as well as their determinants. Relative wages and relative unemployment rates are considered to be the main determinants of these flows. ${ }^{1}$ The chapter estimates the impact of relative wages and relative unemployment rates on migration flows, by using regression methods.

Statistical data on the characteristics (variables) used are taken from the Local Data Bank of the Central Statistical Office and the Ukrainian Statistical Office ${ }^{2}$ (Державна Служба Статистики України) ${ }^{3}$ and refer to the period of 2004-2017. The choice of this time frame is determined by the availability of relevant time series at the voivodeship or peripheral level. 


\subsection{Spatial diversity of migration inflows and outflows rates and their determinants in Poland}

\subsubsection{Inflow rates}

Figure 9.1 presents the evolution of annual rates of migration inflows in groups of voivodeships in the years 2004-2017. These rates are defined as the ratio of the size of migration inflows to a given group of voivodeships in relation to the population in this group of voivodeships. Figure 9.1 shows that:

- The highest migration inflow rates in the entire analyzed period were recorded in the Mazowieckie Voivodeship, and were significantly lower in western Poland than in central Poland, and the lowest rates were in eastern Poland.

- At the beginning of this research period (2004-2007), migration inflow rates were characterized by an upward trend. The highest inflow rate was recorded in the Mazowieckie Voivodeship ( $0.5 \%$, followed by western Poland (0.3\%), central Poland (0.25\%) and eastern Poland (0.2\%).

- In 2008, a sharp decline in migration inflow rates could be observed in all groups of voivodeships. In the Mazowieckie Voivodeship, the rates fell from $0.5 \%$ to below $0.4 \%$, in western Poland from $0.32 \%$ to about $0.27 \%$, in central Poland from $0.27 \%$ to $0.23 \%$, while in eastern Poland from $0.24 \%$ to $0.2 \%$. This was due to the fact that European Union countries opened their labor markets to those countries admitted in 2004. Therefore, migration trends have shifted to other countries.

- Since 2009, the rate of migration inflows to the Mazowieckie Voivodeship has oscillated around $0.4 \%$; nevertheless, this voivodeship was characterized by the largest fluctuations of these inflows. In other regions of Poland, inflow rates remained stable.

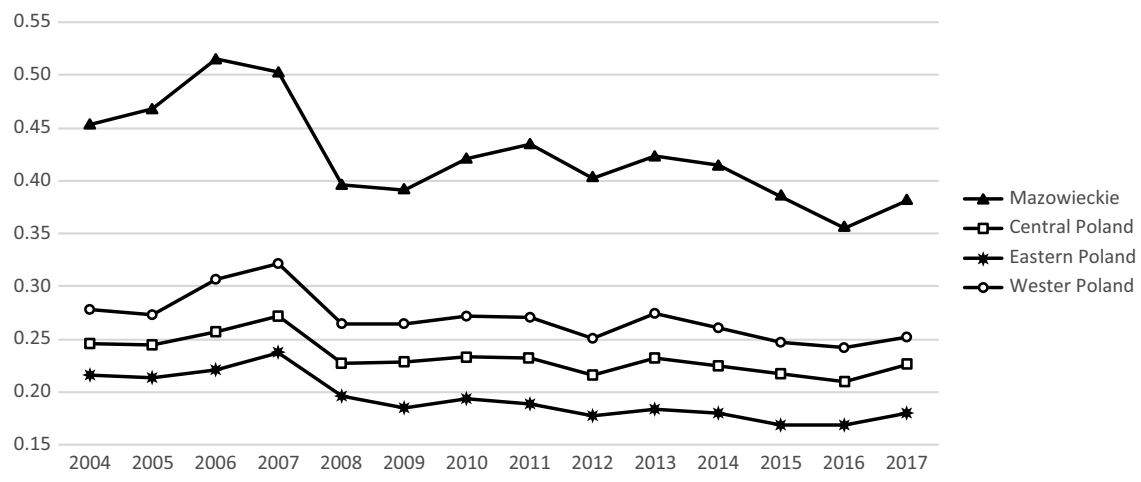

Figure 9.1 Migration inflow rates in voivodship groups in 2004-2017.

Source: Our own estimates based on: https://bdl.stat.gov.pl/BDL/start (access: 2019-12-30). 
[0.159:0.173] (3)

[0.182: 0.222] (3)

[0.225:0.274] (4)

[0.275:0.280] (3)

[0.323:0.424] (3)

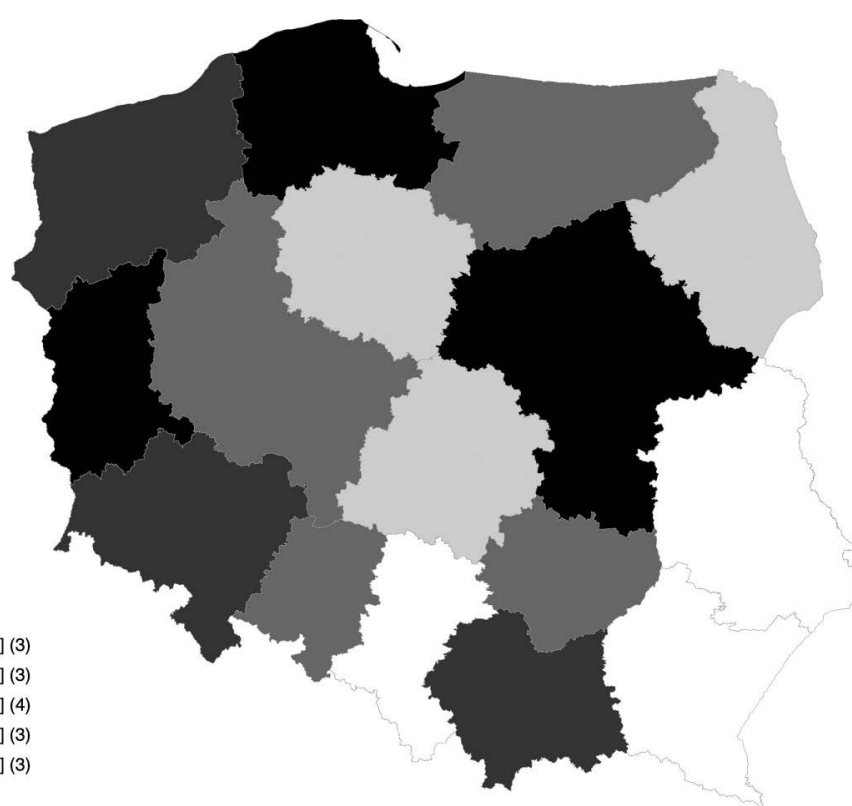

Map 9.1 Spatial differentiation of migration inflow rates in Poland in 2004-2017. Source: Our own estimates based on: https://bdl.stat.gov.pl/BDL/start (access: 2019-12-30).

Map 9.1 presents the spatial differentiation of migration inflow rates, on average in 2004-2017. The following conclusions can be drawn from this fact:

- These inflows were characterized by the highest rates in the Mazowieckie $(0.42 \%)$, Pomorskie $(0.35 \%)$ and Dolnośląskie $(0.28 \%)$ voivodeships.

- The lowest inflow rates, however, were found in the Lubelskie $(0.16 \%)$, Podkarpackie $(0.16 \%)$ and Śląskie $(0.17 \%)$ voivodeships.

- It is worth noting that in the Śląskie Voivodeship, exceptionally low rates of migration inflows were observed. This phenomenon is quite surprising, as the analyzed region has relatively high relative wages and a low unemployment rate.

\subsubsection{Drainage rates}

Figure 9.2 presents the evolution of migration outflows in voivodeship groups (these rates are defined analogously to the inflow rates). The following conclusions can be drawn:

- In the entire analyzed period, eastern Poland was characterized by the highest outflow rates, followed by western and central Poland, and the lowest outflow rates were recorded in the Mazowieckie Voivodeship. 


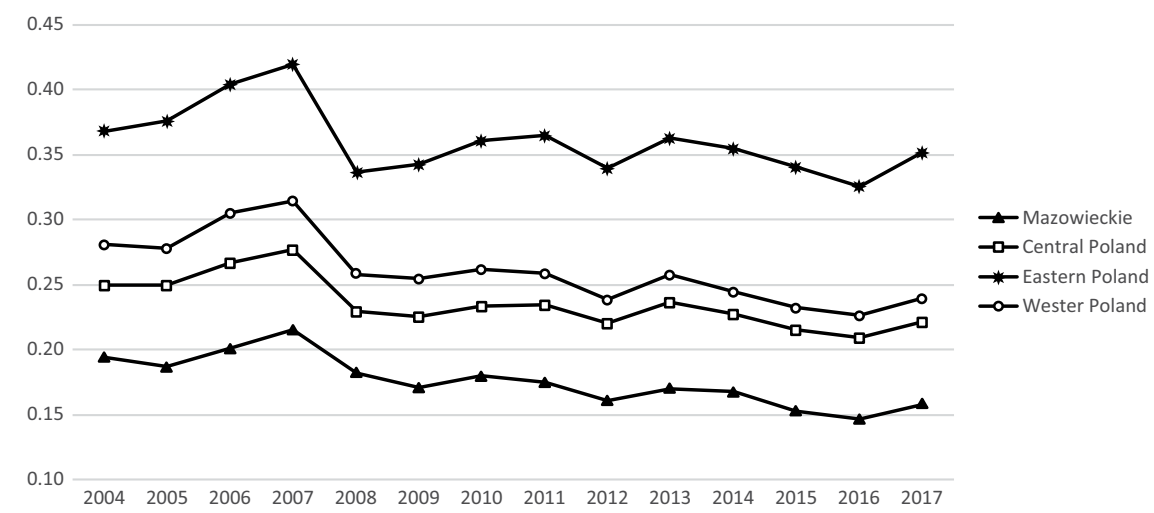

Figure 9.2 Rates of migration outflows in groups of voivodeships in 2004-2017.

Source: Our own estimates based on: https://bdl.stat.gov.pl/BDL/start (access: 2019-12-30).

- At the beginning of the period under review, that is, in the years 20042007, an increase in migration outflow rates can be observed in each group of voivodeships. In eastern Poland from approximately $0.37 \%$ in 2004, these outflows increased to $0.47 \%$ in 2007, in western Poland from $0.33 \%$ to $0.37 \%$, in central Poland from $0.3 \%$ to $0.33 \%$, while in the Mazowieckie Voivodeship from $0.29 \%$ to $0.32 \%$.

- In 2008, a sudden drop in migration outflow rates could be observed to as high as $0.33 \%$ in eastern Poland, $0.31 \%$ in central Poland, $0.28 \%$ in western Poland and $0.28 \%$ in the Mazowieckie Voivodeship. Such large changes, as in the case of inflow rates, were influenced by the opening of the EU labor markets to the Poles.

- Fluctuations in outflow rates have not changed so radically since 2009. For each group of voivodeships, slight declines could be observed from 2013 to 2016, followed by another increase in 2017. At the end of the audited period, the outflow rates for eastern Poland were at $0.4 \%$, western Poland $0.28 \%$, central Poland $0.27 \%$ and the Mazowieckie Voivodeship $0.21 \%$.

Map 9.2 presents the spatial diversity of migration outflow rates in the voivodeship. On this basis it can be concluded that:

- The Warmińsko-Mazurskie $(0.46 \%)$ Voivodeship, followed by the Świętokrzyskie $(0.41 \%)$ and Lubelskie $(0.38 \%)$ voivodeships, had the highest rates of migration outflows.

- The lowest rates are found in the following voivodeships: Małopolskie $(0.17 \%)$, Mazowieckie $(0.18 \%)$ and Wielkopolskie $(0.19 \%)$. 
$[0.174: 0.191](3)$

$[0.223: 0.247](3)$

$[0.259: 0.329](4)$

$[0.333: 0.379](3)$

$[0.382: 0.455](3)$

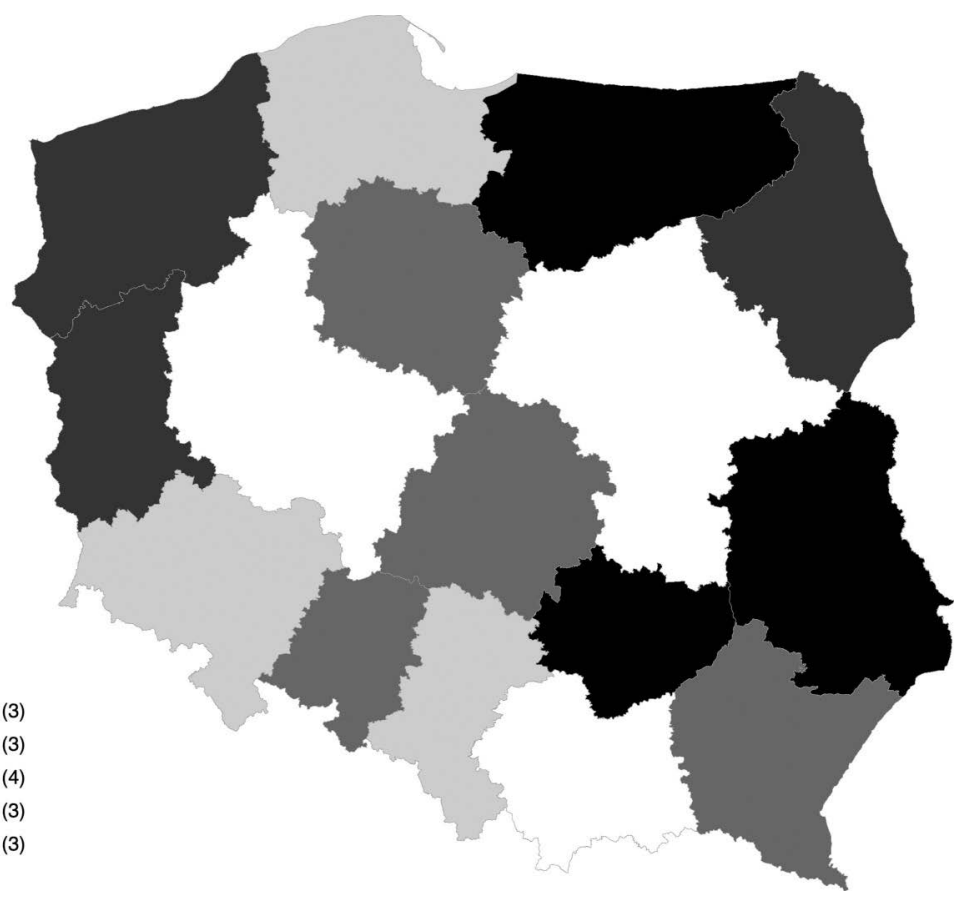

Map 9.2 Spatial differentiation of rates of migration outflows in Poland in 2004-2017.

Source: Our own estimates based on: https://bdl.stat.gov.pl/BDL/start (access: 2019-12-30).

\subsubsection{Net inflow rates}

Figure 9.3 shows the trajectories of net migration rates (understood as differences between inflow rates and outflow rates) in groups of voivodeships in 2004-2017. From this figure it can be concluded that:

- Over the entire period under review, the highest net migration rates were recorded in the Mazowieckie Voivodeship, while the lowest were in the voivodeships of eastern Poland. Central Poland and western Poland were characterized by similar migration balances, while in the first half of the analyzed period, that is, 2004-2010, central Poland had a higher migration balance, while from 2011 on, western Poland had higher net rates.

- The voivodeships of eastern Poland were characterized by the largest diversification of net migration inflows. In 2006, the migration balance was the lowest and amounted to about $-0.9 \%$ for this part of the country. In 2008, the largest increase was observed to be around $-0.7 \%$.

- In central and western Poland, net inflow rates were not characterized by large fluctuations. Throughout the entire research period, these 


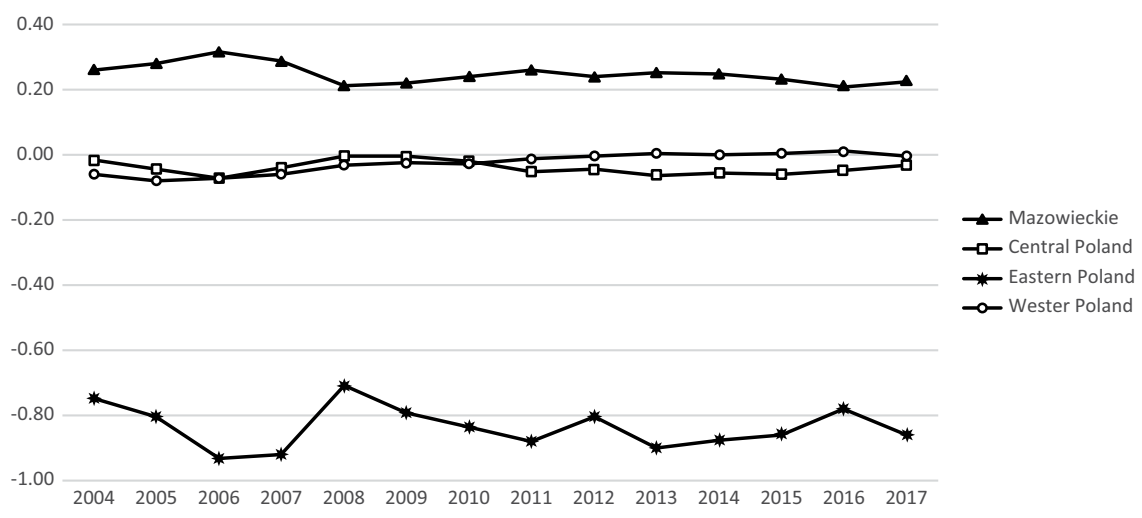

Figure 9.3 Migration balance rates in voivodeship groups in 2004-2017.

Source: Our own estimates based on: https://bdl.stat.gov.pl/BDL/start (access: 2019-12-30).

fluctuations ranged from $-0.07 \%$ to $0.01 \%$. It can be seen that since 2011 , net migration rates for central Poland have stabilized at around $-0.05 \%$, and for western Poland at $0 \%$.

- Net inflow rates in the Mazowieckie Voivodeship fluctuated around $0.25 \%$ in the whole research period with slight fluctuations. It is worth noting that at the beginning (2004-2007) net migration rates were the highest, while in 2008 there was the largest decrease, and that since then, there have been no major changes.

The spatial differentiation of migration balances was presented on Map 9.3. The following conclusions can be drawn from this map:

- The following voivodeships had the highest net migration rates: Mazowieckie $(0.25 \%)$, Pomorskie $(0.12 \%)$ and Małopolskie $(0.10 \%)$. It is worth noting that the difference between the Mazowieckie Voivodeship and the others is substantial.

- However, the lowest levels of migration balances were found in the Lubelskie $(-0.22 \%)$, followed by Świętokrzyskie $(-0.19 \%)$ and WarmińskoMazurskie (-0.18\%) voivodeships.

- Negative migration balances were also evident in the following voivodeships: Podlaskie $(-0.15 \%)$, Podkarpackie $(-0.10 \%)$, Śląskie $(-0.07 \%)$, Kujawsko-Pomorskie $(-0.07 \%)$, Lódzkie $(-0.07 \%)$, Opolskie $(0.07 \%)$ Lubuskie $(-0.06 \%)$ and Zachodniopomorskie $(-0.06 \%)$.

- Apart from the voivodeships mentioned at the beginning, only two voivodeships have positive migration balances, the Wielkopolskie $(0.05 \%)$ and Dolnośląskie $(0.05 \%)$, hence the conclusion that the Mazowieckie Voivodeship is dominant and absorbs the population of other voivodeships. 

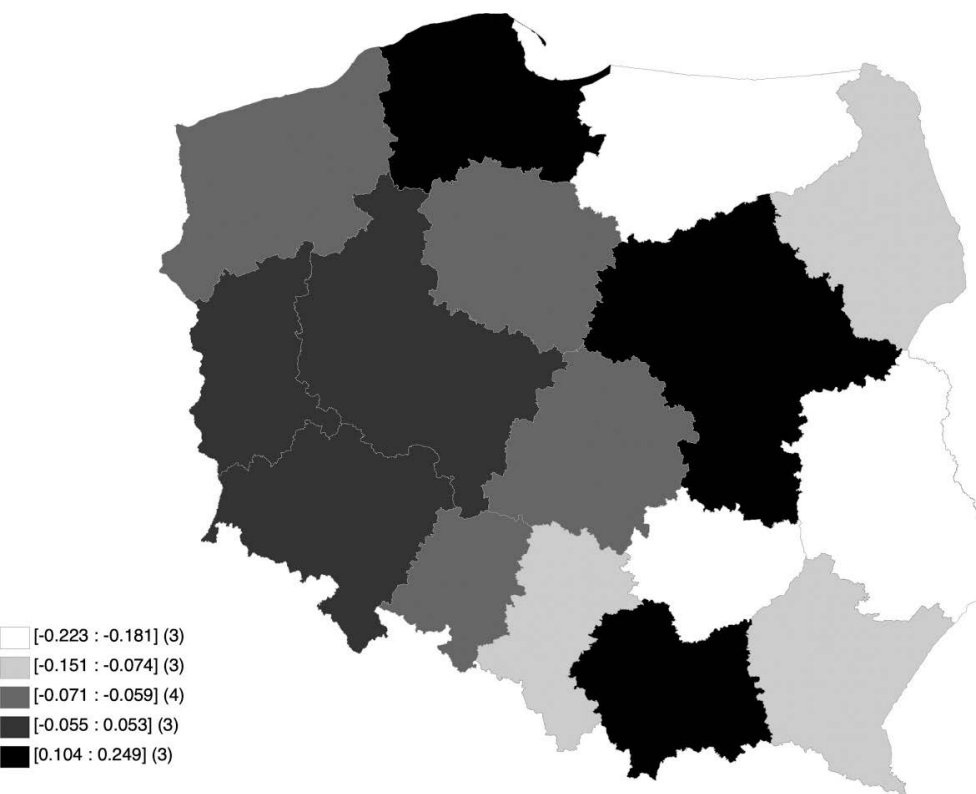

Map 9.3 Spatial diversity of migration balances in Poland.

Source: Our own estimates based on: https://bdl.stat.gov.pl/BDL/start (access: 2019-12-30).

\subsubsection{Relative wages}

Figure 9.4 presents the relative wages in voivodeship groups. The following conclusions can be drawn from this figure:

- The Mazowieckie Voivodeship was characterized by the highest relative wages throughout the entire research period. It is worth noting that only in this case, did we observe a downward trend in relative wages from around 1.33 in 2004 to approximately 1.25 in 2017. Nevertheless, despite the downward trend in relative wages, the gap between the Mazowieckie Voivodeship and other groups of voivodeships is quite significant.

- Central Poland came in second in terms of wages. During the whole period under review, this part of the country was characterized by a relative wage stability of around 0.98 of the national average.

- Slightly lower levels of relative wages were recorded in western Poland. In the analyzed period this variable oscillated at around 0.95 of the average value. It is worth noting that in 2017 there was a noteworthy alignment between wages in western Poland and wages in the central part of the country.

- Eastern Poland had the lowest relative wages. In this group of voivodeships, wages were around 0.88 of the national average. Similarly, to central and western Poland, this variable, except for slight fluctuations, was constant over time. 


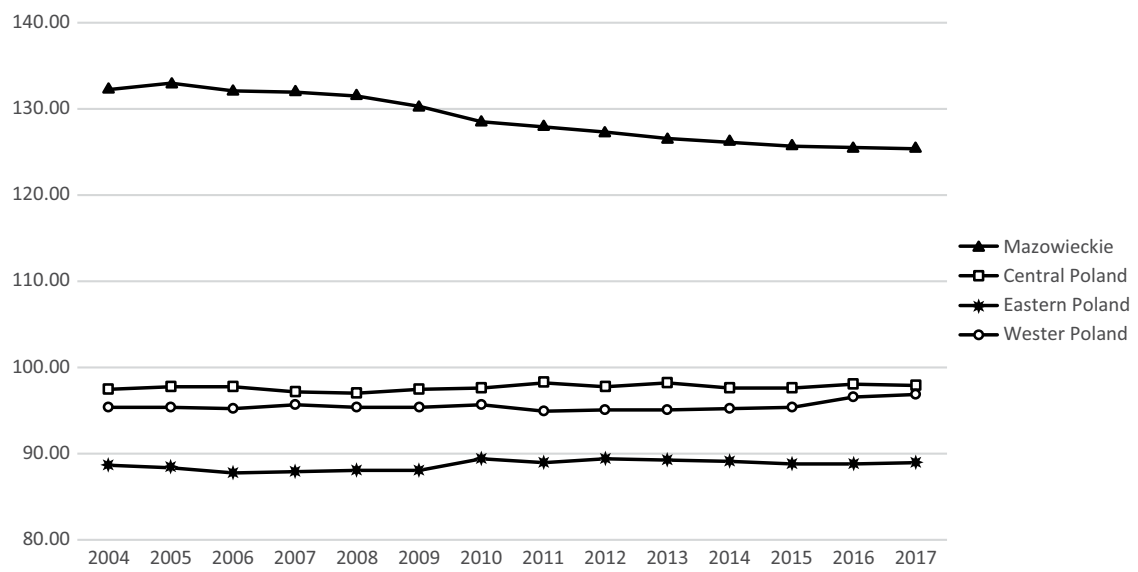

Figure 9.4 Relative wages in voivodeship groups in 2004-2017.

Source: Our own estimates based on: https://bdl.stat.gov.pl/BDL/start (access: 2019-12-30).

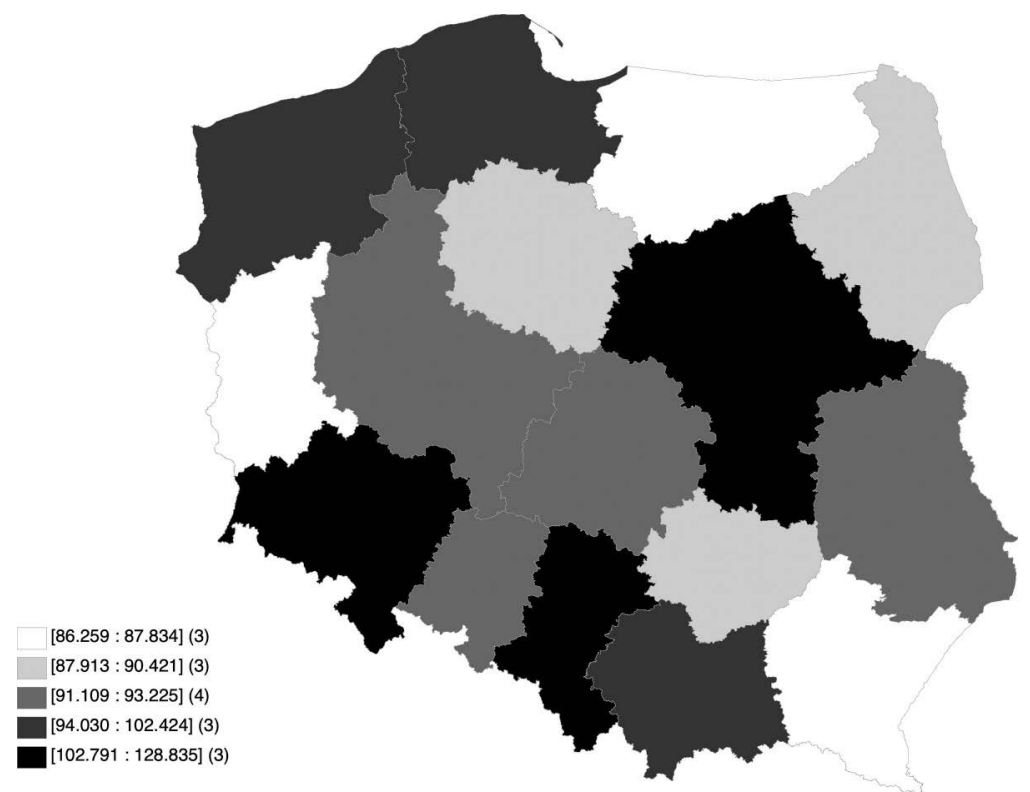

Map 9.4 The spatial differentiation of relative wages in Poland.

Source: Our own estimates based on: https://bdl.stat.gov.pl/BDL/start (access: 2019-12-30).

The spatial differentiation of relative wages is presented on Map 9.4. The following conclusions can be drawn from this map:

- The highest relative wages were recorded in the Mazowieckie (1.29), Śląskie (1.05) and Dolnośląskie (1.03) voivodeships. It is notable that 
there was a substantial difference - over $20 \%$ points - between the Mazowieckie Voivodeship and the remaining ones.

- The lowest wages were recorded in the Podkarpackie (0.86), then in the Warmińsko-Mazurskie (0.86) and finally in the Lubuskie (0.88) voivodeships.

- It is also important that apart from the three voivodeships with the highest relative wages, only the Pomorskie Voivodeship had wages above the national average (1.02). Therefore, it can be concluded that the Mazowieckie Voivodeship surpassed the other voivodeships in terms of wages and significantly increases the national average.

\subsubsection{Relative unemployment rates}

Figure 9.5 presents the relative unemployment rate in voivodeship groups. The following conclusions can be drawn:

- The relative variation in the unemployment rate was large. At the beginning of the period under review (i.e., 2004-2008), a downward trend in the relative unemployment rate can be seen for western and central Poland and the Mazowieckie Voivodeship. However, in the case of eastern Poland, a clear increase in the analyzed variable can be observed during the same period.

- Since 2009, an increase in the relative unemployment rate can be observed in the Mazowieckie Voivodeship and in central Poland. In the case of western Poland, a downward trend is still observed. In contrast, in eastern Poland there was a decrease in relative unemployment rates until 2013.

- At the end of the period under review, an increase in the relative unemployment rate in eastern Poland can again be observed. In the case of other groups of voivodeships, slight decreases of this variable can be noticed.

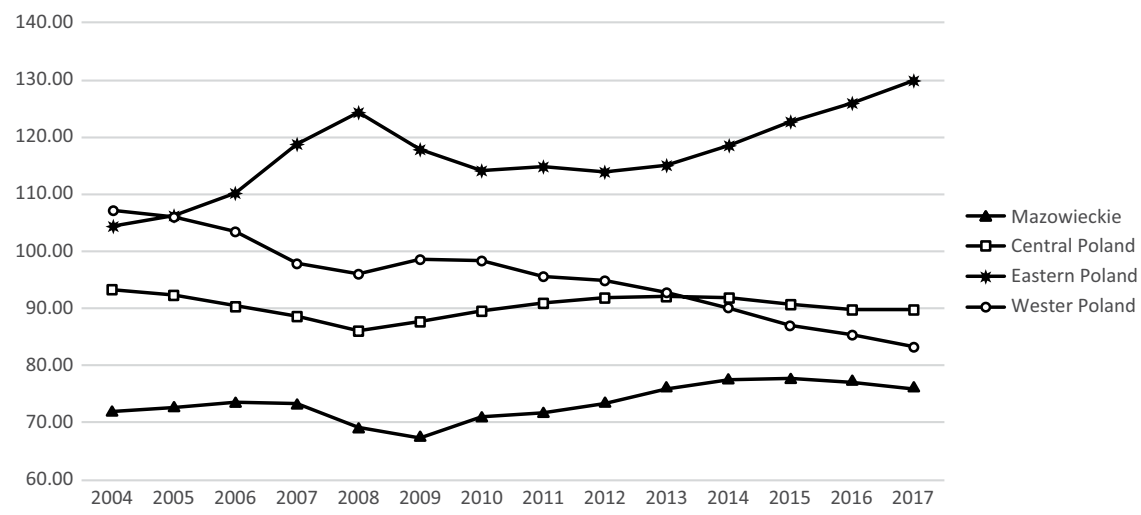

Figure 9.5 Relative unemployment rates in voivodeship groups in 2004-2017.

Source: Our own estimates based on: https://bdl.stat.gov.pl/BDL/start (access: 2019-12-30). 


\subsection{A spatial differentiation of migration inflow and outflow rates and their determinants in Ukraine}

\subsubsection{Inflow rates}

Figure 9.6 illustrates the rates of inflow in groups of oblasts of Ukraine in 2004-2017. This shows that:

- Strong factors influencing internal migration include the political and social stability in a country. In particular, the observed decline in 2009 was caused by the political crisis and the global financial crisis.

- Very substantial changes in the inflow rates were recorded in 2014-2016, which resulted from the military-political conflict in southern and eastern Ukraine and the occupation of Crimea.

- The group of northern Ukraine oblasts had the highest relative rates of migration inflows, in particular a very high rate was recorded in the Kyiv Oblast (1.82\%) and the City of Kyiv (1.69\%).

- The substantial decline in 2016 was caused by the underdevelopment in the new law of the procedure for transferring data from the State Migration Service to the State Statistics Service of Ukraine.

- In 2014, a sharp decline in migration inflow rates in eastern Ukraine could be observed.

The reason for this was that the war began in the Luhansk and Donetsk oblasts.

Map 9.5 presents the relative inflow rates in the oblasts of Ukraine. The following conclusions can be drawn:

- The highest inflow rates were recorded in the Kyiv Oblast $(1.82 \%)$, the City of Kyiv $(1.69 \%)$, the Sumy Oblast $(1.63 \%)$, the Poltava Oblast $(1.63 \%)$ and the Kharkiv Oblast (1.61\%).

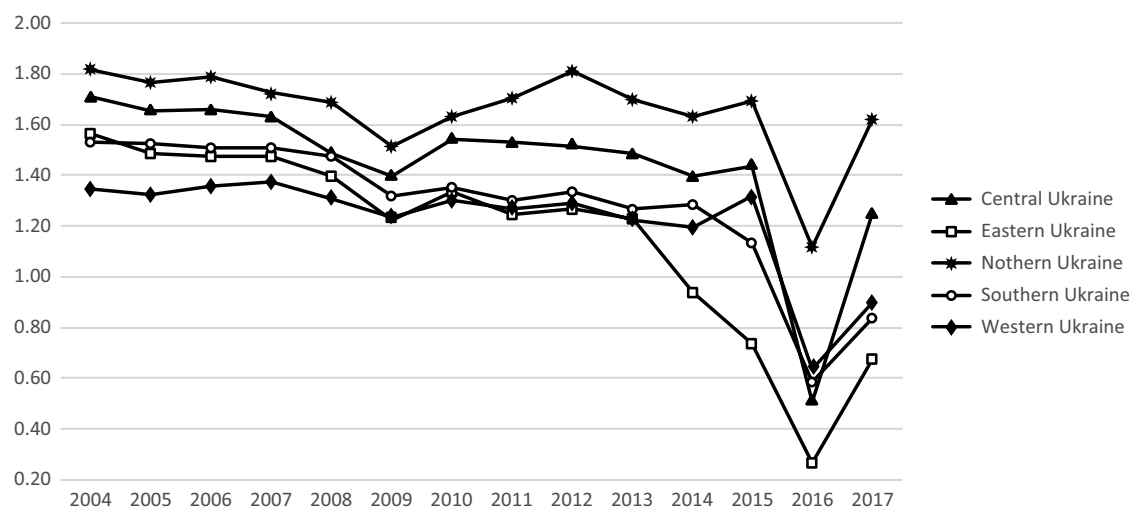

Figure 9.6 Rates of migration inflows in groups of oblasts in 2004-2017.

Source: Our own estimates based on: http://www.ukrstat.gov.ua/ (access: 2019-12-30). 


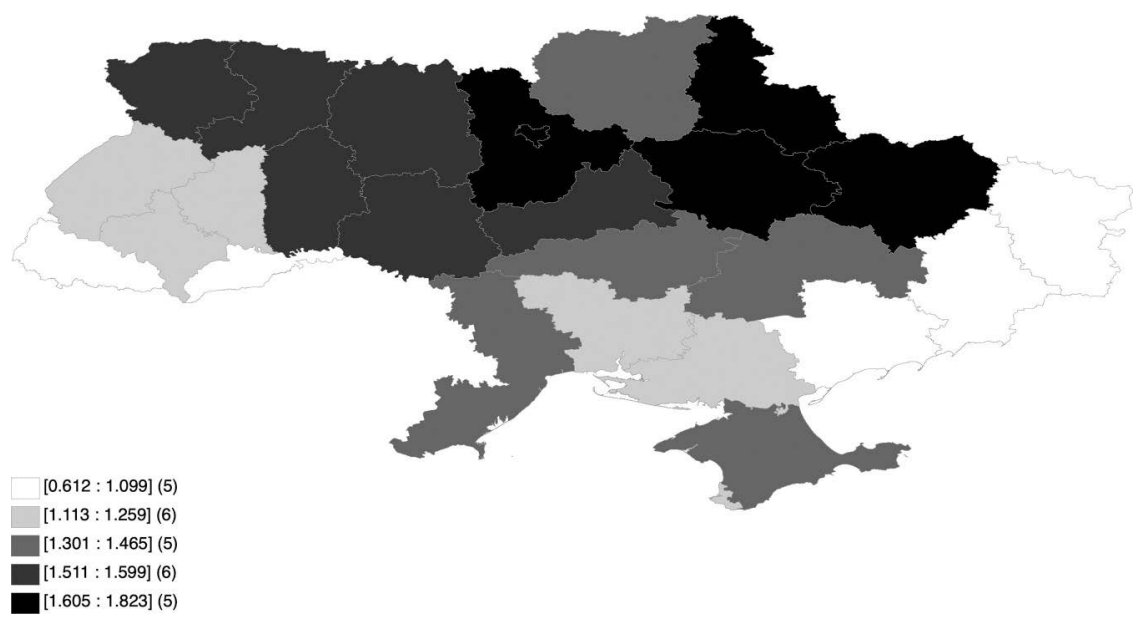

Map 9.5 Spatial differentiation of rates of migration inflows in Ukraine.

Source: Our own estimates based on: http://www.ukrstat.gov.ua/ (access: 2019-12-30).

- The lowest values of the analyzed variable were observed in the Zakarpattia $(0.61 \%)$, Donetsk $(0.97 \%)$, Chernivtsi $(1.10 \%)$, Zaporizhzhya $(1.10 \%)$ and Luhansk $(1.05 \%)$ oblasts.

- In interregional migrations, the main beneficiary was the City of Kyiv and the Kyiv Oblast. In 2000, the increase in the capital's population, at the expense of other regions, reached 20,000 people for the year. During the current migration crisis, growth has decreased (from 14.4 thousand people in 2014 to about 12,000 people in 2015), but it still remains the highest in Ukraine. It is worth noting that this data applies only to officially approved migrations, and does not include temporary and forced migrations. $^{4}$

- The observed distribution of migration inflow rates can be explained by the fact that many of the population living in small underdeveloped areas decided to move to oblasts with larger cities, where it is easier to find a job, earn a higher salary and enjoy a better lifestyle.

\subsubsection{Outflow rates}

The general regularity of the impact of political and social stability on migration processes of the population is reflected in the dynamics of indicators of relative outflow rates in groups of oblasts of Ukraine, which is presented in Figure 9.7.

The following conclusions can be drawn:

- The trajectories of relative rates of migration outflows in groups of oblasts of Ukraine were similar. 


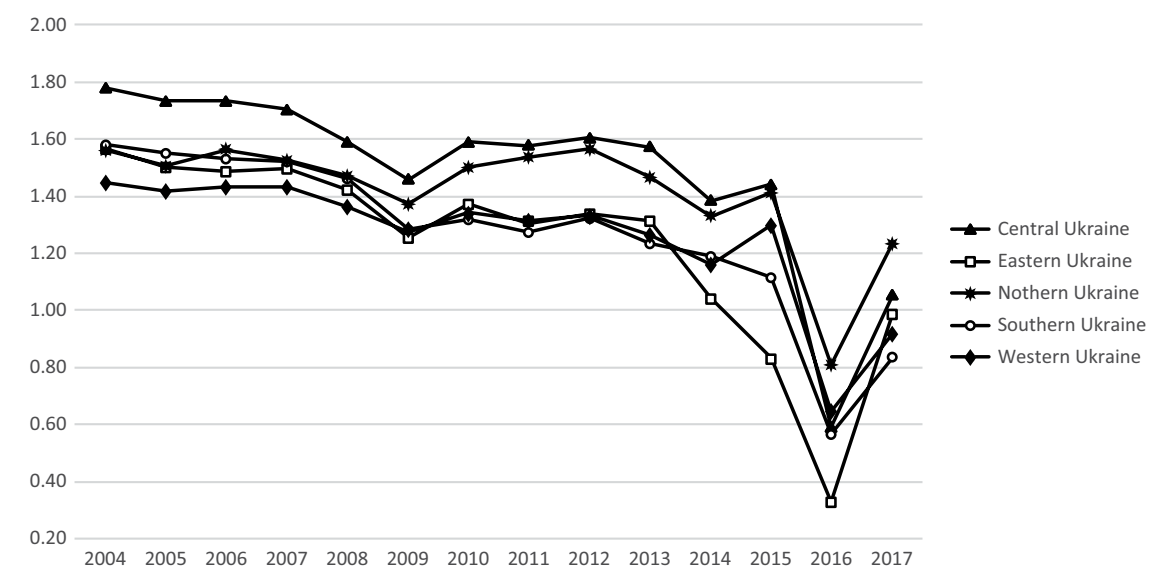

Figure 9.7 Rates of migration outflows in circuit groups in 2004-2017.

Source: Our own estimates based on: http://www.ukrstat.gov.ua/ (access: 2019-12-30).

- In 2004, central Ukraine (1.78\%) had the highest relative rates of outflows, while western Ukraine $(1.45 \%)$ had the lowest. At the beginning of the period under review, a slight downward trend in migration outflows can be observed in all groups of oblasts.

- After slight increases in the years 2010-2013, a significant decrease of the analyzed variable can be detected in all parts of the country, especially in western Ukraine, to a level of $0.65 \%$ in 2016. Against the background of the economic and political crisis in Ukraine, starting from 2013, the material situation of those people with medium and low incomes had deteriorated. Many people were forced to look for a job which provided a higher income. For people from western Ukraine, it was more convenient and more profitable to travel abroad (to Europe) than looking for a job in other regions of Ukraine.

The average rates of migration outflows in the oblasts of Ukraine are shown on Map 9.6. This map shows that:

- The highest relative rates of outflows were recorded in the underdeveloped oblasts of Ukraine, that is, the Poltava (1.64\%), Vinnytsya $(1.65 \%)$, Zhytomyr (1.69\%), Rivne (1.71\%), and Sumy (1.75\%) oblasts.

- The lowest rates of this variable were observed in the Zakarpattia $(0.69 \%)$, Sevastopol $(0.83 \%)$, Chernivtsi $(1.05 \%)$, and Donetsk oblasts $(1.09 \%)$ and the City of Kyiv $(1.10 \%)$.

- Starting from 2014, strong internal migrations in Ukraine, of a mandatory nature, were caused by the annexation of Crimea and military operations in the Donbas. According to information from the 


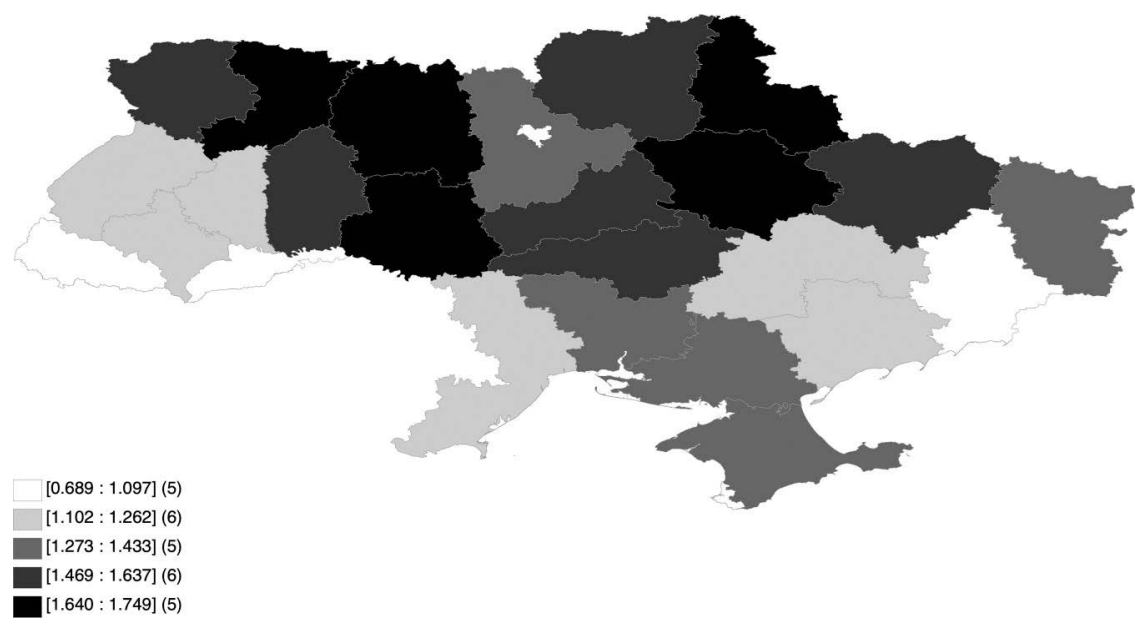

Map 9.6 Spatial differentiation of the rates of migration outflows in Ukraine. Source: Our own estimates based on: http://www.ukrstat.gov.ua/ (access: 2019-12-30).

Inter-ministerial coordination of the staff for social security of displaced persons (HVE), as of July 20, 2016 from areas outside the Government's sphere of influence, 1,029,571 people were forced to move to other regions of Ukraine, mainly from the Donetsk and Luhansk Oblasts, who numbered 1,007,112 people; from the Autonomous Republic of Crimea and the city of Sevastopol 22,459 people. The grand total included 170,581 children and 495,093 who were either disabled or elderly. ${ }^{5}$

\subsubsection{Net inflow rates}

Net inflow rates in 2004-2017 are presented in Figure 9.8. The following conclusions can be drawn from this figure:

- Net inflow rates in 2004-2017 were very diverse.

- Northern Ukrainian oblasts have become more attractive to the migrant population. Over 14 years, this indicator for northern Ukraine increased from $0.4 \%$ in 2004 to $1.56 \%$ in 2017 . This situation was affected by the war and political conflict, as many people streamed into the City of Kyiv and to the Kyiv region from eastern Ukraine.

- In northern Ukraine, in the years 2004-2013 a weak upward trend in net migration could be detected. However, since 2014 a strong decrease may be observed, which was due to the fact that the State Statistics Service of Ukraine does not provide data on the Autonomous Republic of Crimea and the city of Sevastopol, and in addition fewer, and fewer 


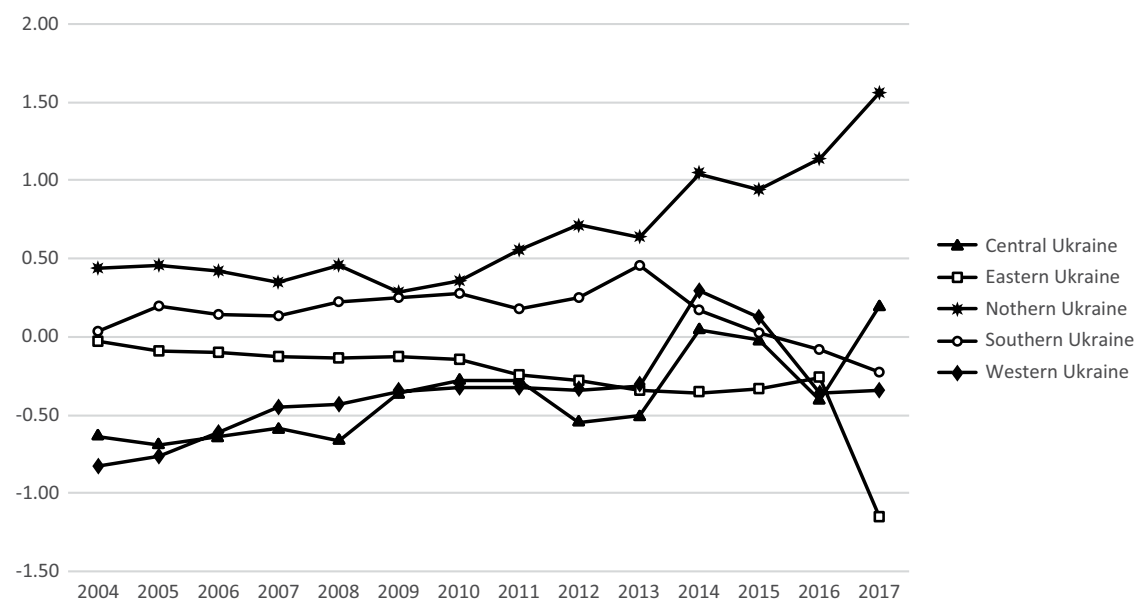

Figure 9.8 Net migration inflow rates in groups of oblasts in 2004-2017.

Source: Our own estimates based on: http://www.ukrstat.gov.ua/ (access: 2019-12-30).

people want to live close to territories where military operations are taking place.

- Net inflow rates in central and western Ukraine were at a similar level. From 2004 to 2014, these parts of the country were characterized by negative migration balances, but an upward trend can be perceived during this period. Then in 2016 it fell below zero again.

Net migration inflows in individual oblasts are presented on Map 9.7. This map shows that:

- The highest net inflow rates were recorded in the City of Kyiv $(0.593 \%)$ and Sevastopol $(0.431 \%)$, then in the Kyiv $(0.391 \%)$, Kharkiv $(0.137 \%)$ and Odesa $(0.085 \%)$ oblasts.

- The lowest net inflow rates were recorded in the following oblasts: Kirovohrad (-0.248\%), Luhansk (-0.220\%), Kherson (-0.190\%), Sumy $(-0.117 \%)$ and Donetsk $(-0.115 \%)$.

- In the period of 2004-2017, the directions of migration in Ukraine were caused by the hope in people that they could realize their full potential outside their then-current permanent place of residence. For most migrants, the main motive for their trip was the desire to get a (better) job, improve their employment conditions and raise their standard of living. From 2014, migrations were caused by the desire to avoid participation in military activities, which could have posed a threat to life and health, also impediments to, or a lack of, business opportunities. 


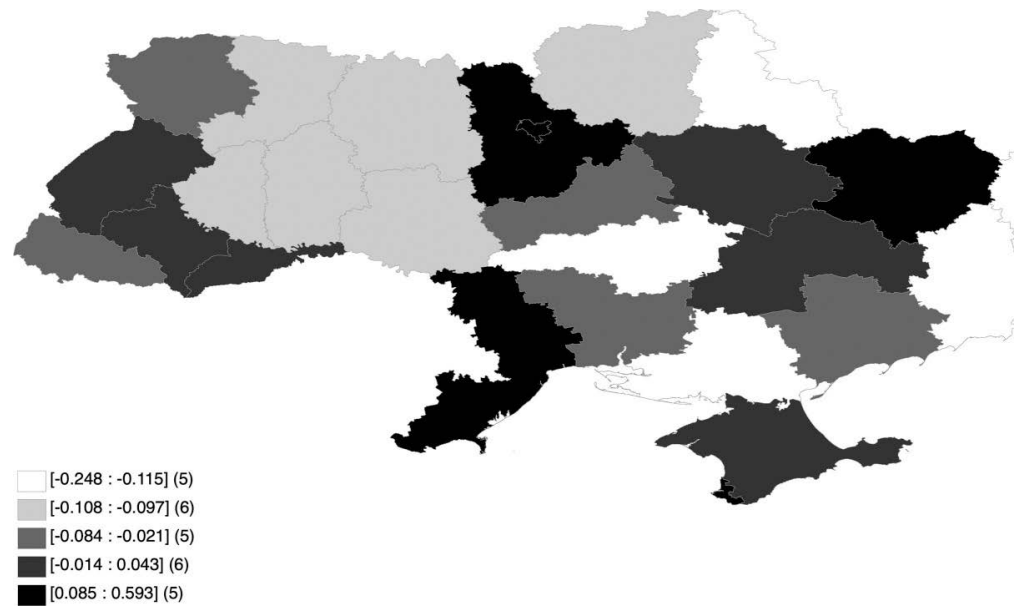

Map 9.7 Spatial differentiation of the rates of net migration inflows in Ukraine. Source: Our own estimates based on: http://www.ukrstat.gov.ua/ (access: 2019-12-30).

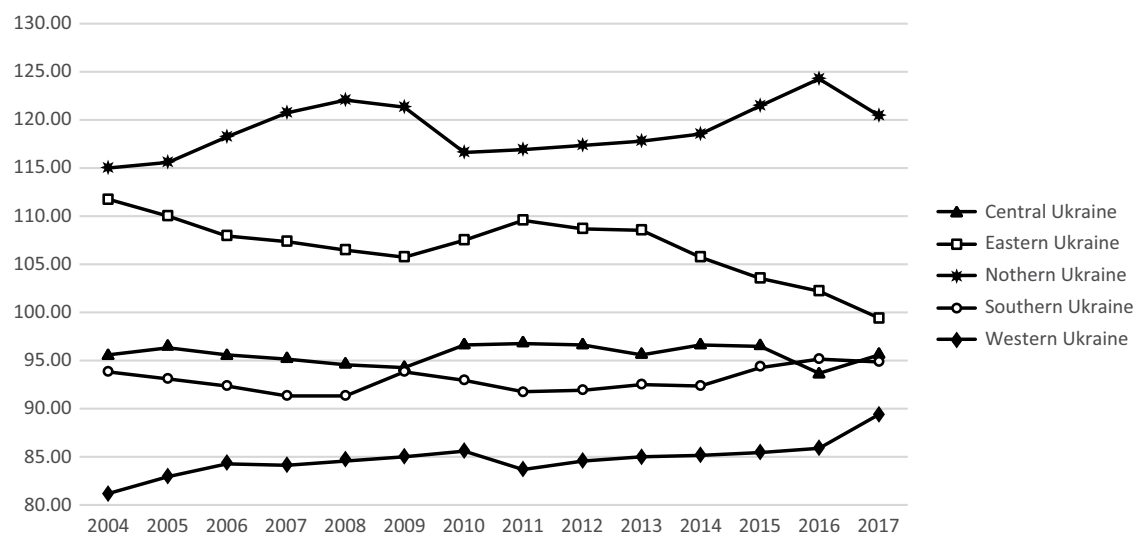

Figure 9.9 Relative wages in oblast groups in 2004-2017.

Source: Our own estimates based on: http://www.ukrstat.gov.ua/ (access: 2019-12-30).

\subsubsection{Relative wages}

Figure 9.9 illustrates the relative wages in groups of Ukrainian oblasts. The following conclusions can be drawn:

- The highest relative wages were recorded in northern Ukraine - in 2016 they amounted to 1.25 of the average salary in Ukraine, this was mainly due to the relatively high wages in Kyiv. 


\section{Nataliia Chugaievska and Daniela Szczepaniak}

- Wages above the national average were also characteristic of eastern Ukraine, because this part of the country is largely associated with industry - there are iron and steel mills and hard (anthracite) coal mines.

- In 2004, this analyzed variable remained at a similar level in eastern and northern Ukraine, but within 14 years the disparity between the wages of these parts of the country increased to $1 \%$ in eastern Ukraine and to $1.2 \%$ in northern Ukraine in 2017.

- Relative wages below the national average were recorded in southern and western Ukraine. These are underdeveloped regions, from which many people leave in order to search for better living conditions.

- In central Ukraine, relative wages fluctuated around zero with slight changes.

Map 9.8 presents the spatial differentiation of relative wages in Ukraine. This map shows that:

- The highest relative wages were recorded in the City of Kyiv (1.67) and the Donetsk (1.19), Dnipropetrovsk (1.09), Kyiv (1.06) and Zaporizhzhya oblasts (1.05).

- The lowest indicators of this variable were recorded in the Volyn (0.79), Chernivtsi (0.80), Chernihiv (0.80), Kherson (0.80) and Ivano-Frankivsk $(0.88)$ oblasts.

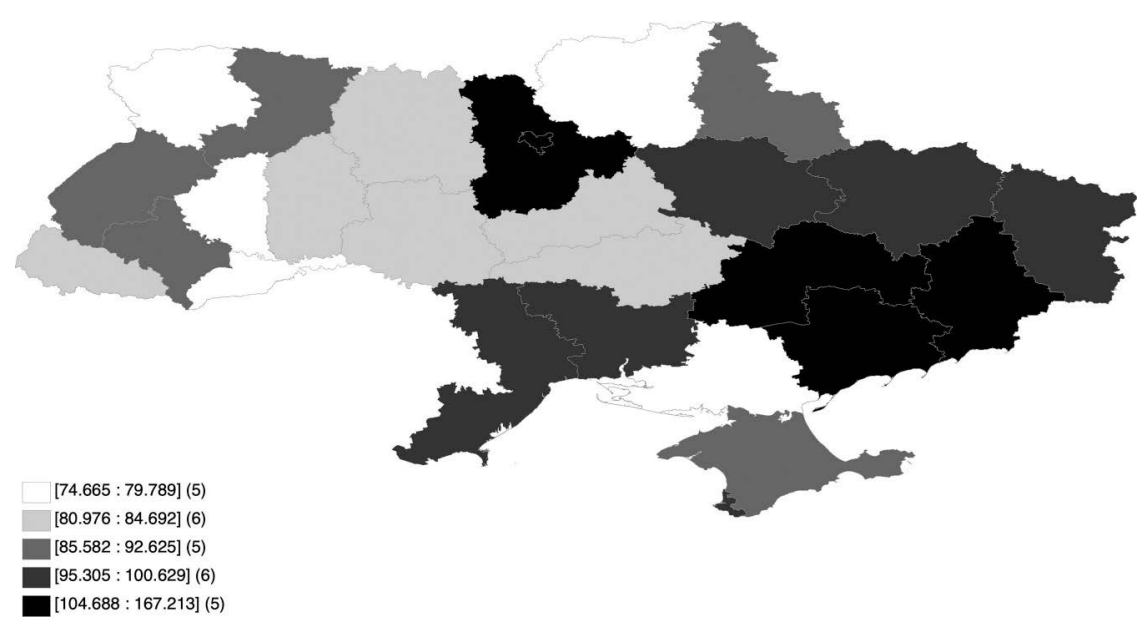

Map 9.8 Spatial differentiation of relative wages in Ukraine.

Source: Our own estimates based on: http://www.ukrstat.gov.ua/ (access: 2019-12-30). 


\subsubsection{Relative unemployment rates}

The dynamics of the relative unemployment rate in Ukraine in 2004 2017 are presented in Figure 9.10. The following conclusions can be drawn:

- The dynamics of the relative unemployment rates in Ukraine in 2004 2017 varied widely.

- With the start of the armed conflict with Russia in 2014, in eastern Ukraine, the relative unemployment rate increased sharply to 1.19 in 2017.

- A strong downward trend in the unemployment rate can be observed in western Ukraine. However, these charts may be misleading, because people go abroad and remain registered as unemployed in Ukraine.

- Since 2011, the relative unemployment rate in northern Ukraine has been decreasing, which indicates the creation of new jobs.

At the end of 2017, 354,400 people were registered in the State Employment Service as unemployed citizens. Seven people applied for every job vacancy. However, according to national analysts, the information provided by the State Statistical Service reduces the actual level of unemployment by about five times. ${ }^{6}$ The consequence of this is the presence of multidimensional hidden unemployment.

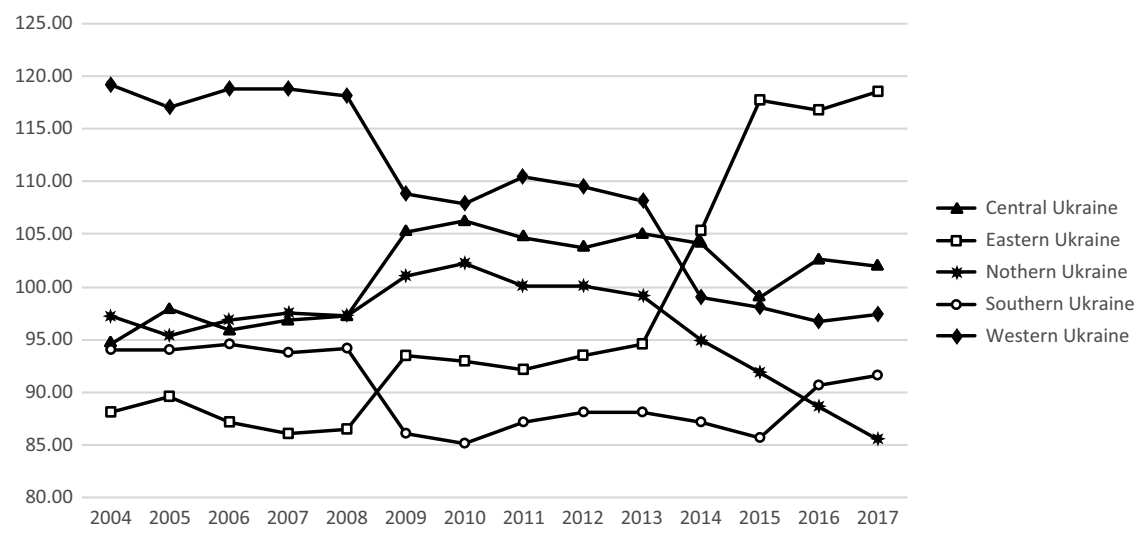

Figure 9.10 Relative unemployment rate in oblast groups in 2004-2017.

Source: Our own estimates based on: http://www.ukrstat.gov.ua/ (access: 2019-12-30). 


\subsection{A statistical analysis of the impact of relative wages and relative unemployment rates on migration flows}

In order to examine the impact of relative wages and relative unemployment rates on migration flows, the parameters of the equations of the linear (9.1) and logistic (9.2) functions were estimated as:

$$
\begin{aligned}
& m_{i t}=\alpha+F E+\alpha_{w} \frac{w_{i t}}{\bar{w}_{t}}+\alpha_{U} \frac{u_{i t}}{\bar{u}_{t}}, \\
& m_{i t}=\frac{1}{1+\exp \left(\alpha+F E+\alpha_{w} \frac{w_{i t}}{\bar{w}_{t}}+\alpha_{U} \frac{u_{i t}}{\bar{u}_{t}}\right)},
\end{aligned}
$$

where $m_{i t}$ is the inflow rate, outflow rate or migration balance in a voivodeship/oblast $i$ and in year $t$, FE is the individual effects, $w_{i t}$ is the wages in a voivodeship/oblast $i$ in year $t, \bar{w}_{t}$ is the average wage in the country in year $t$. $u_{i t}$ is the unemployment rate in a voivodeship/region $i$ and in year $t$, and $\bar{u}_{t}$ is the unemployment rate in the country in the year $t$.

The parameters of Eqs. (9.1) and (9.2) were estimated by the following estimation methods: ordinary least squares (OLS), OLS with fixed effects in space, OLS with fixed effects in space and time, generalized method of moments (GMM), GMM with fixed effects in space, GMM with individual effects in space and time, a logistic model, a logistic model with individual effects in space, a logistic model with individual effects in space and time.

Estimates of the parameters of Eqs. (9.1) and (9.2) for Poland are presented in Table 9.1. The following conclusions can be drawn:

- In estimations in which the rate of migration inflows is the explained variable, the relative wages in most cases had a statistically significant and positive impact on these inflows. Only in the logistic model with individual effects was this interaction not significant. ${ }^{7}$

- The impact of the relative unemployment rate on the analyzed variable was no longer so unambiguous. In models without individual effects, this impact was positive and statistically significant. Only in the equation of the logistic function with the effects in space and time was the impact of the relative unemployment rate statistically significant and negative. Other models indicated the insignificance of this variable.

- Comparing the absolute values of Student's $t$ statistics with the explanatory variables, it can be noticed that relative wages significantly influenced the rate of migration inflows.

- Comparing corrected coefficients of determination for models without individual effects, it can be seen that the variability of the dependent variable was best explained with the Ordinary least squares (OLS) method in approx. 39.3\%, then the Generalized Method of Moments (GMM) $38.6 \%$ and the logistics model (logit model) $29.0 \%$. 


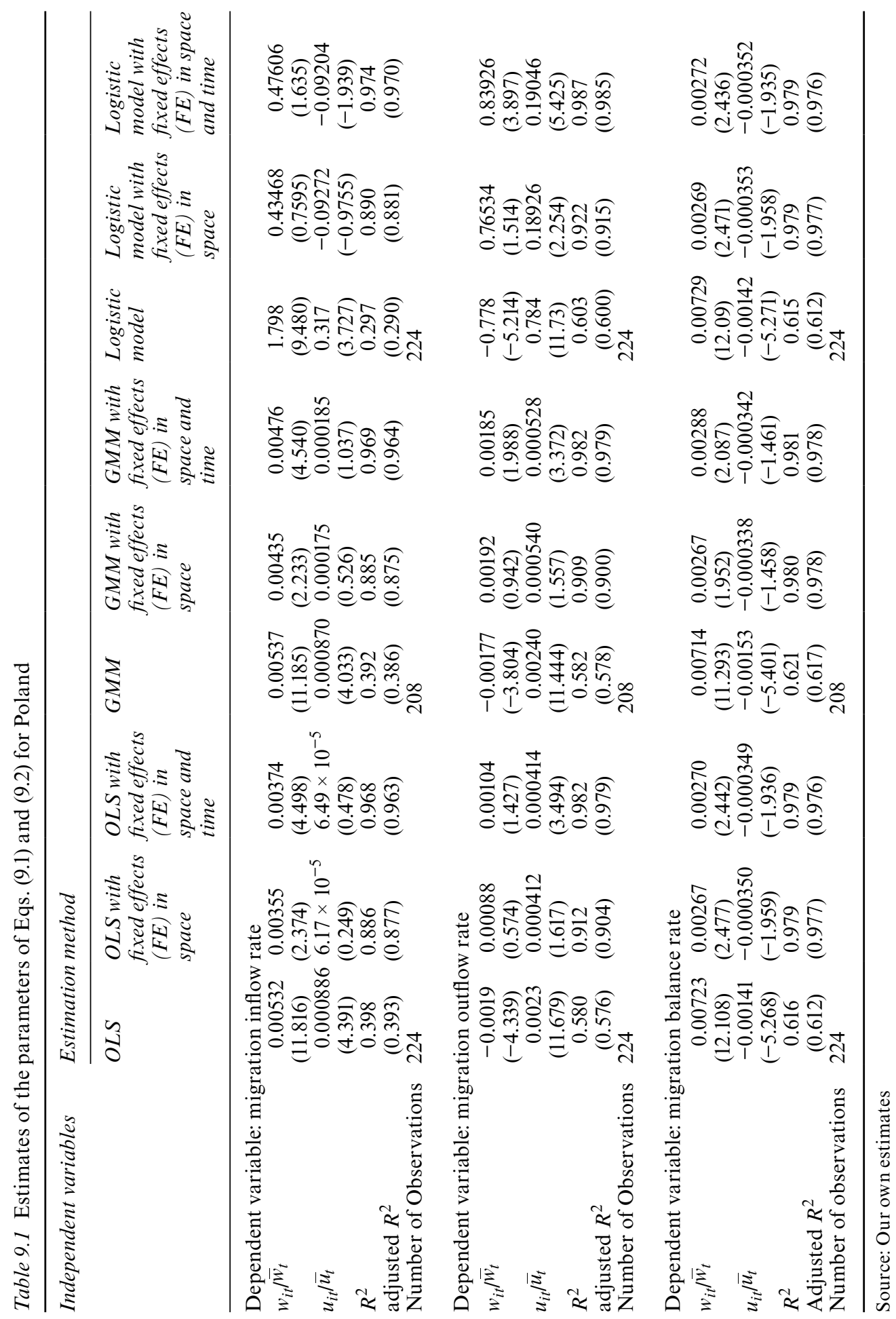


- In the estimations of Eqs. (9.1) and (9.2), when the dependent variable was the rate of migration outflows, the impact of relative wages on this variable was not unequivocal. In the estimations of models without individual effects, the impact was statistically significant and negative. Only in the case of the GMM model with effects in space and time and the logistic model with effects in space and time was the impact of relative wages positive and statistically significant. Other estimation methods indicated the statistical insignificance of the variable in question.

- The impact of relative unemployment rate on migration outflows in all estimation methods turned out to be statistically positive. Only in the OLS model with effects in space and GMM with effects in space was this variable insignificant. In other cases, the relative rate had a statistically significant effect.

- Comparing the absolute values of Student's $t$ statistics for independent variables, it should be stated that it was the relative unemployment rate that had a significant impact on migration outflows.

- Analyzing the corrected coefficients of determination (without individual effects), it can be seen that the variability of the dependent variable is best described by the logistics model $(60.0 \%)$, then GMM $(57.8 \%)$ and OLS $(57.6 \%)$.

- Estimations of Eqs. (9.1) and (9.2), in which the dependent variable was the net migration rate [A2] [A2], relative wages had a positive and statistically significant effect on the net migration rate for each estimation method.

- The impact of the relative unemployment rate was negative and statistically significant in OLS estimations with and without fixed effects, the logistic model (with and without effects) and GMM without fixed effects. Only in the case of GMM models with individual effects did this variable turn out to be statistically insignificant.

- Comparing the absolute values of $t$ statistics with independent variables, it should be stated that relative wages were the more significant variable.

- Analyzing the values of the adjusted coefficient of determination, it can be seen that the variability of the dependent variable was best explained by the GMM model at about $61.7 \%$, for the OLS and the logistic model, it was $61.2 \%$.

Estimates of the parameters of Eqs. (9.1) and (9.2) for Ukraine are presented in Table 9.2. For Ukraine, only those equations are analyzed, in which the dependent variable is the rate of migration balances, because in other cases the results were not satisfactory and their interpretation would not make sense. The following conclusions can be drawn from the estimates in Table 9.2: 


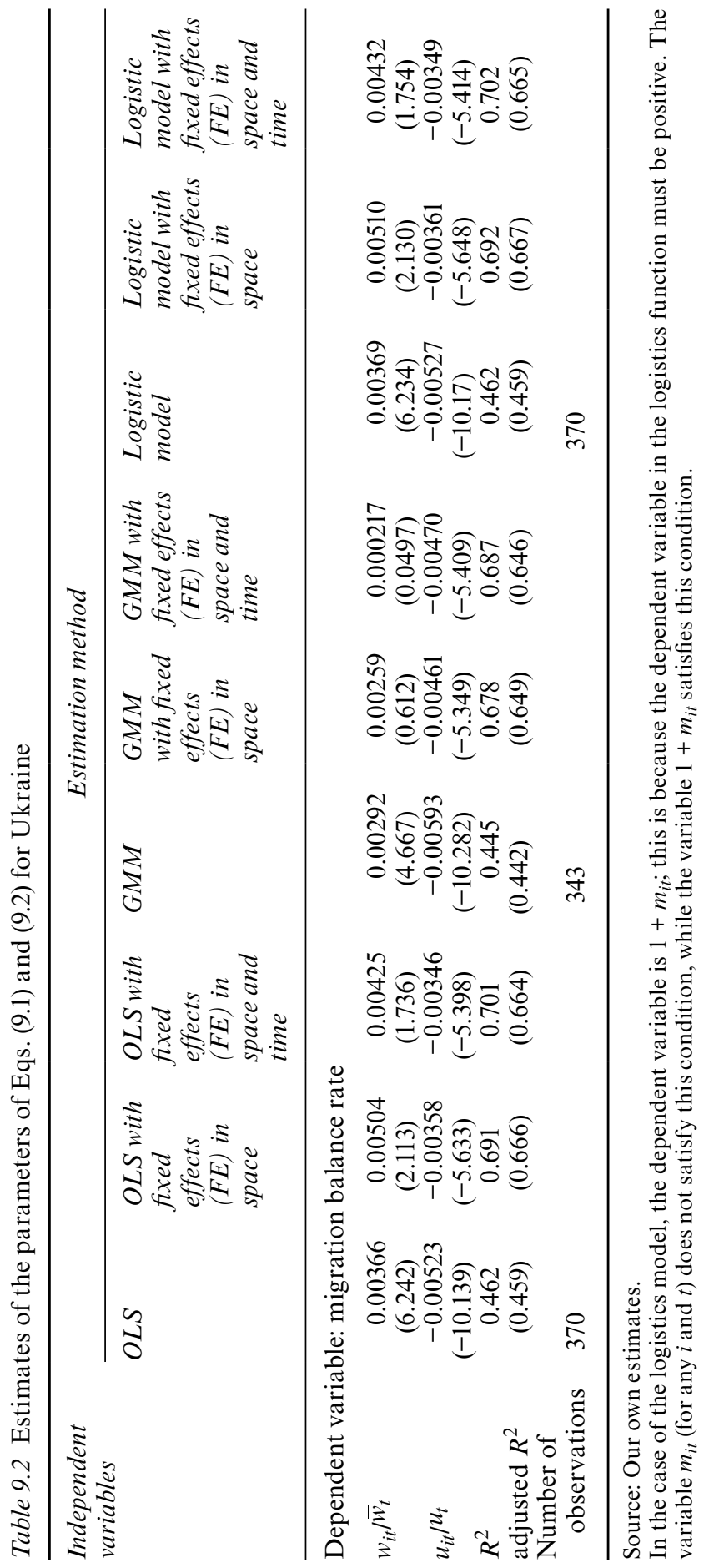


- Relative wages had a positive and statistically significant effect ${ }^{8}$ on the examined dependent variable in OLS estimations (with and without effects), the logistic model (with and without effects) and GMM. In GMM estimations with individual effects, this variable turned out to be statistically insignificant.

- The impact of the relative unemployment rate was negative and statistically significant in each estimation method.

- Comparing the absolute values of Student's $t$ statistics, it turned out that relative unemployment was a more significant variable.

- Analyzing the corrected coefficients of determination (in models without individual effects), it can be seen that the variability of the dependent variable was best explained by the OLS and logistics model in about $45.9 \%$, while the GMM model $44.2 \%$.

For Poland, the authors also estimated the parameters of the following equations:

$$
\begin{aligned}
\frac{M_{i j t}}{P_{i t}} & =\alpha+\mathrm{FE}+\alpha_{W} \frac{w_{j t}}{w_{i t}}+\alpha_{U} \frac{u_{j t}}{u_{i t}}+\alpha_{D} \ln \left(d_{i j}\right), \\
\frac{M_{i j t}}{P_{i t}} & =\frac{1}{1+\exp \left(\alpha+\mathrm{FE}+\alpha_{W} \frac{w_{j t}}{w_{i t}}+\alpha_{U} \frac{u_{j t}}{u_{i t}}+\alpha_{D} \ln \left(d_{i j}\right)\right)},
\end{aligned}
$$

where $M_{i j t}$ is the number of people migrating from and to the voivodeship $j$ in year $t, P_{i t}$ is the number of people living in the voivodeship $i$ and in year $t, w_{i t}, w_{j t}$ is the wages in voivodeships $i$ and $j$ in year $t, u_{i t}, u_{j t}$ is the unemployment rate in a voivodeship $i$ and $j$ in year $t$, and $d_{i j}$ is the distance (in a straight line) between voivodeships $i$ and $j$.

The estimation of the parameters of Eqs. (9.3) and (9.4) was made using the following estimation methods: OLS, OLS with effects over time, GMM, GMM with effects over time, logistics model and logistics model with effects over time. Models with individual effects in space were not analyzed, as distances between voivodeship capitals are a linear combination of effects in space. In addition, due to a lack of data, it was impossible to create models for Ukraine.

Estimates of the parameters of Eqs. (9.3) and (9.4) are presented in Table 9.3. The following conclusions can be drawn from these estimates:

- The ratio of wages in the voivodeship $j$ to wages in the voivodeship had a positive and statistically significant effect $^{9}$ on migration flows between these voivodeships,

- The relation of the unemployment rate in the voivodeship $j$ to the unemployment rate in the voivodeship $j$ had a negative and statistically significant effect on the dependent variable,

- The distance between the capitals of individual voivodeships had a negative, statistically significant impact on migration flows between those voivodeships, 
Table 9.3 Estimates of the parameters of Eqs. (9.3) and (9.4)

\begin{tabular}{|c|c|c|c|c|c|c|}
\hline \multirow{2}{*}{$\begin{array}{l}\text { Independent } \\
\text { variables }\end{array}$} & \multicolumn{6}{|c|}{ Estimation method } \\
\hline & $O L S$ & $\begin{array}{l}\text { OLS with } \\
\text { fixed } \\
\text { effects } \\
(\text { FE) in } \\
\text { time }\end{array}$ & $G M M$ & $\begin{array}{l}G M M \\
\text { with fixed } \\
\text { effects } \\
(F E) \text { in } \\
\text { time }\end{array}$ & $\begin{array}{l}\text { Logistic } \\
\text { model }\end{array}$ & $\begin{array}{l}\text { Logistic } \\
\text { model fixed } \\
\text { effects (FE) } \\
\text { in time }\end{array}$ \\
\hline$w_{j t} / w_{i t}$ & $\begin{array}{l}0.000934 \\
(29.977)\end{array}$ & $\begin{array}{l}0.000935 \\
(29.992)\end{array}$ & $\begin{array}{l}0.000948 \\
(26.456)\end{array}$ & $\begin{array}{l}0.000948 \\
(26.458)\end{array}$ & $\begin{array}{l}0.000943 \\
(29.98)\end{array}$ & $\begin{array}{l}2.66991 \\
(23.53)\end{array}$ \\
\hline$u_{j t} / u_{i t}$ & $\begin{array}{c}-2.31 \times \\
10^{-5} \\
(-1.855)\end{array}$ & $\begin{array}{c}-2.24 \times \\
10^{-5} \\
(-1.791)\end{array}$ & $\begin{array}{c}-1.64 \times \\
10^{-5} \\
(-1.117)\end{array}$ & $\begin{array}{c}-1.61 \times \\
10^{-5} \\
(-1.094)\end{array}$ & $\begin{array}{c}-2.40 \times \\
10^{-5} \\
(-1.858)\end{array}$ & $\begin{array}{l}-0.350844 \\
(-7.719)\end{array}$ \\
\hline $\ln d_{i j}$ & $\begin{array}{l}-0.000217 \\
(-28.664)\end{array}$ & $\begin{array}{l}-0.000217 \\
(-28.671)\end{array}$ & $\begin{array}{l}-0.000214 \\
(-27.019)\end{array}$ & $\begin{array}{l}-0.00214 \\
(-27.028)\end{array}$ & $\begin{array}{l}-0.000219 \\
(-28.67)\end{array}$ & $\begin{array}{l}-1.00431 \\
(-36.42)\end{array}$ \\
\hline $\begin{array}{l}\mathrm{R}^{2} \\
\text { Adjusted } \mathrm{R}^{2}\end{array}$ & $\begin{array}{l}0.401 \\
(0.401)\end{array}$ & $\begin{array}{l}0.404 \\
(0.401)\end{array}$ & $\begin{array}{l}0.395 \\
(0.394)\end{array}$ & $\begin{array}{l}0.398 \\
(0.395)\end{array}$ & $\begin{array}{l}0.401 \\
(0.401)\end{array}$ & $\begin{array}{l}0.436 \\
(0.433)\end{array}$ \\
\hline $\begin{array}{l}\text { Number of } \\
\text { observations }\end{array}$ & 3,360 & & 3,120 & & 3,360 & \\
\hline
\end{tabular}

Source: Our own estimates.

- When comparing the absolute values of these statistics, it should be stated that the distance between voivodeship capitals and the pay ratio were more significant variables than the unemployment rate ratio.

- Analyzing the corrected coefficient of determination (in models without individual effects) it can be seen that the variability of the dependent variable was best explained by the logistics model and OLS in about $40.1 \%$, while GMM $39.4 \%$.

\subsection{Summary}

i In Poland, the rate of migration inflows was statistically significantly positive on relative wages, while the impact of the relative unemployment rate was not so clear. Hence, one can conclude that the factor attracting migrants to a given voivodeship was the desire to find a better-paying job.

ii In the case of the migration outflow rate, the relative unemployment rate was a variable that had a positive, statistically significant effect on these outflows, while it is difficult to discern the clear impact of relative wages. This means that the factor determining migration from a given province was the inability to find a job.

iii In the net migration balance, both the relative wages and the relative unemployment rate were statistically significant. In the case of wages, the impact was positive, while unemployment was negative. It is worth noting that wages were a more important variable.

iv In the case of Ukraine, the net migration balance was negatively affected by the relative statistical rate of unemployment. The impact of relative 
wages was positive, but not always statistically significant, which means that the population decided to migrate because of being unable to find a job.

v The model describing inter-voivodeship migrations in Poland shows that the most important factor negatively and statistically significant for these migrations is the distance between voivodeship capitals. The ratio of wages between pairs of provinces had a slightly weaker but positive impact on migration. However, the ratio of unemployment rates had the weakest impact on the dependent variable. This means that people who decide to migrate are more likely to choose voivodeships that are closer to their current place of residence, and at the same time those where wages are higher.

\section{Notes}

1 Relative wages (the relative unemployment rate) are understood to be the quotient of wages (unemployment rates) in a given province or region and wages (unemployment rates) in the entire economy.

2 https://bdl.stat.gov.pl/BDL/start (access: 2019-12-30).

3 http://www.UKRSTAT.gov.ua/ (access: 2019-12-30).

4 International Organization for Migration, Mihratsiia yak chynnyk rozvytku $v$ Ukraini (Міграція як чинник розвитку в Україні), 2016. Access: http://www. iom.org.ua/sites/default/files/mom_migraciya_yak_chynnyk_rozvytku_v_ ukrayini.pdf.

5 Mihratsiia v Ukraini: fakty i tsyfry 2016. Access: http://iom.org.ua/sites/default/ files/ff_ukr_21_10_press.pdf.

6 Sirochuk N.A. (2014), Mizhnarodna trudova mihratsiia ukraintsiv do krain yevropeiskoho soiuzu: faktory vplyvu. Access: http://economy.kpi.ua/files/files/12_ kpi_2014.doc.

7 The variable can be considered statistically significant at a level of 5\% when the absolute value of the statistics given in brackets is greater than the critical value of Student's $t$-distribution (1.65).

8 The variable should be considered statistically significant at the level of $5 \%$ when the absolute value of the statistics given in brackets is greater than 1.65 .

9 The variable should be considered statistically significant at the level of $5 \%$ when the absolute value of the statistics given in brackets is greater than 1.645. 